\title{
Scientia Traductionis, última edição Scientia Traductionis, last issue
}

O tema de nosso editorial traz-nos à lembrança o conhecido pensamento de Plauto (ca. 230 - ca. 180 a.C.), em Bacchides (IV,7), Quem di diligunt, adulescens moritur, dum ualet sentit sapit [Quem os deuses amam, morre jovem, enquanto está saudável, perceptivo e sábio]. Este número 16 é a última edição de Scientia Traductionis.

Em cumprimento à solicitação apresentada pela Capes, seja, a de reduzir o número de revistas ligadas a um mesmo Programa de Pós-Graduação, o Colegiado da Pós-Graduação em Estudos da Tradução da UFSC determinou o encerramento do periódico Scientia Traductionis.

Desde 2010, quando a ST passou por uma completa reestruturação e lançou a edição Uma nova Scientia Traductionis, este periódico produziu edições de qualidade, cuidadosamente revisadas e, em colaboração com os autores e conselheiros, com textos retrabalhados por muitas vezes até estarem prontos para publicação. As seções, nas quais os trabalhos são distribuídos, compuseram-se de Trabalhos Traduzidos, Artigos, Dossiês, Traduções Comentadas, Ensaios e Entrevistas. Vale ressaltar que, destas, a primeira sempre nos encantou como algo 'novo' ao possibilitar a publicação bilíngue de textos 'antigos' sobre tradução, em tradução ao português brasileiro. E em todas, o objetivo sempre foi a qualidade.

Nesta última edição, como noutras vezes, ainda contamos com a presença de autores clássicos, articulistas, tradutores e resenhistas contemporâneos, e com assuntos os mais variados, todos
The subject of this editorial brings to mind the well-known thought of Plautus (ca. 230 - ca. 180 BC) in Bacchides (IV, 7): Quem di diligunt, adulescens moritur, dum ualet sentit sapit [Whom the gods love dies young, while he's strong, clever and wise]. As it is, this issue 16 of Scientia Traductionis is its last.

Pursuant to a request by Capes, i.e., to reduce the number of journals linked to one individual Graduate Program, the Postgraduate Translation Studies Program at UFSC has decided to discontinue Scientia Traductionis.

Since 2010, when ST underwent a complete revamp and its 'inaugural' issue, entitled A new Scientia Traductionis, was published, the journal has put out quality issues, whose texts, in collaboration with authors and peer reviewers, have been carefully reviewed and reworked until being considered ready for publication. The journal's sections included: Translated Texts, Articles, Dossiers, Translations with commentaries, Essays, and Interviews. It is worthy of note that the first section listed has always struck the editors as a 'novelty', since it promoted the bilingual publication of 'older' texts about translation into Brazilian Portuguese. All in all, producing quality issues has always been the chief goal of the editors.

In this last issue, as in previous ones, we still publish classical authors, as well as contemporary ones, translators and reviewers, and tackle a variety of subjects, all connected to the main 
costurados pelo tema da área: a tradução subject area: translation and its practice e sua prática em diferentes épocas, in different eras, by diverse means, and meios, concepções e teorias. according to different concepts and theories.

A todos, nosso sincero agradeci- To all, our sincerest gratitude. mento.

Uma última vez, boa leitura!

One last time, happy readings!

\author{
Mauri Furlan \\ Gustavo Althoff
}

Florianópolis, junho de 2016 